\title{
RESTRUKTURISASI KEWENANGAN GUNA MENDUKUNG PENGELOLAAN RUANG LAUT YANG BERDAULAT DAN BERKELANJUTAN
}

(Restructuring of Authority to Support Sovereign and Sustainable Sea Space Management)

\author{
Yerrico Kasworo \\ Pusat Analisis dan Evaluasi Hukum Nasional \\ Badan Pembinaan Hukum Nasional \\ J. Mayjen Soetoyo No. 10 Cililitan, Jakarta Timur \\ E-mail: yerricokasworo@gmail.com
}

Naskah diterima: 2 Agustus 2019; revisi: 27 Agustus 2019; disetujui: 28 Agustus 2019

\begin{abstract}
Abstrak
Indonesia memiliki visi menjadi negara poros maritim dunia yang berdaulat, maju, mandiri, dan kuat, serta memberikan kontribusi positif bagi keamanan dan perdamaian kawasan dunia. Dalam rangka mewujudkan visi tersebut maka di dalam Rencana Pembangunan Jangka Menengah Nasional (RPJMN) Tahun 2015 - 2019 terkait dengan pengeloaan sumber daya kelautan dan kemaritiman menjadi program penting bagi bangsa Indonesia. Tulisan ini mencoba mengangkat permasalahan tumpang tindih kewenangan instansi terkait di dalam pengelolaan ruang laut, melalui metode penelitian yuridis normatif maka diperoleh kesimpulan bahwa tedapat tumpang tindih kewenangan antar instansi berdasarkan regulasi yang ada dalam hal penegakan hukum di laut Indonesia. Tidak hanya itu, koordinasi antar penegak hukum juga lemah sehingga seringkali terjad benturan kewenangan. Ada juga kebijakan masing-masing instansi yang menimbulkan konflik kepentingan. Oleh sebab itu maka koordinasi antar berbagai instansi akan sangat menentukan keberhasilan dalam penegakan hukum di laut Indonesia.
\end{abstract}

Kata Kunci: laut, maritim, pengelolaan ruang laut, penegakan hukum

\begin{abstract}
The vision of Indonesia to become a sovereign, developed, independent, world maritime axis country with positive contribution for national interest of security and peace must be promoted concurrently with reform of various aspects. Therefore, the National Mid-Term Development Plan for the Year 2015 - 2019 on Marine and Maritime Resources has been the focused attention for the government. In the National Mid-Term Development Plan 2015-2019 the Management of Marine and Maritime Resources has been the main focus and agenda of the national development where Indonesia is expected to strengthen its identity as a maritime country. Indonesian maritime is a complex issue which involves law enforcement. The issue of law enforcement may be resolved by giving priority to reform of regulation and integrated coordination among all relevant authorities.
\end{abstract}

Keywords: sea, maritime, sea space management, law enforcement 


\section{A. Pendahuluan}

Indonesia merupakan negara kepulauan terbesar di dunia dengan $3 / 4 \quad$ Wilayah negara berupa perairan. Data yang dilansir oleh Kementerian Koordinator Bidang Kemaritiman menyatakan bahwa luas total perairan Indonesia sebesar $6.400 .000 \mathrm{~km}^{2}$ yang di dalamnya terdapat kurang lebih 17.504 pulau dan 16.056 di antaranya telah dibakukan dan disubmisi oleh PBB. Sebagai negara kepulauan, Indonesia memiliki potensi sumber daya kelautan yang begitu besar dan potensi kemaritiman yang dapat dimanfaatkan dan dilestarikan. ${ }^{1}$

Hal tersebut melatarbelakangi Visi negara Indonesia untuk menjadi negara poros maritim dunia yaitu dengan menjadi negara maritim yang berdaulat, maju, mandiri, kuat, serta mampu memberikan kontribusi positif bagi keamanan dan perdamaian kawasan dunia. Atas dasar hal tersebut pada Rencana Pembangunan Jangka Menengah Nasional Tahun 2015 - 2019 terkait dengan pengeloaan sumber daya kelautan dan kemaritiman menjadi salah satu fokus rencana pembangunan yang akan dilakukan oleh pemerintah, yang diharapkan dapat memperkuat jati diri bangsa menjadi negara maritim.

Maritim dalam Kamus Besar Bahasa Indonesia diartikan sebagai segala sesuatu yang berkenaan dengan laut; berhubungan dengan pelayaran dan perdagangan di laut. Dalam bahasa Inggris, kata yang digunakan untuk menunjukkan sifat atau kualitas yang menyatakan penguasaan terhadap laut adalah seapower. Istilah maritim juga mengandung ambiguitas. Apakah maritim yang dimaksud adalah maritim dalam pengertian sempit yaitu hanya berhubungan dengan angkatan laut atau angkatan laut dalam hubungan dengan kekuatan darat dan udara, atau bahkan dalam arti yang seluas-luasnya, yaitu angkatan laut dan semua kegiatan yang berhubungan dengan penggunaan komersial non-militer terhadap laut. Dilihat dari arti kata secara luas, kata kelautan mungkin lebih cenderung mengartikan laut sebagai wadah, yaitu sebagai hamparan air asin yang sangat luas yang menutupi permukaan bumi, hanya melihat fisik laut dengan segala kekayaan alam yang terkandung di dalamnya. Dengan demikian, istilah maritim sesungguhnya lebih komprehensif, yaitu tidak hanya melihat laut secara fisik, wadah dan isi, tetapi juga melihat laut dalam konteks geopolitik, terutama posisi Indonesia dalam persilangan antara dua benua dan dua samudra serta merupakan wilayah laut yang sangat penting bagi perdagangan dunia. Pengertian ini sesuai pula dengan Kamus Besar Bahasa Indonesia yang mengartikan maritim sebagai berkenaan dengan laut; berhubungan dengan pelayaran dan perdagangan di laut. ${ }^{2}$

Sebagai negara kepulauan dengan luas wilayah laut yang sangat besar, percepatan pembangunan kelautan merupakan tantangan yang harus diupayakan untuk kesejahteraan seluruh rakyat Indonesia. Untuk menjadikan Indonesia sebagai poros maritim dunia, tantangan yang dihadapi salah satunya adalah perlunya memperkuat penegakan kedaulatan dan yurisdiksi nasional berdasarkan konvensi PBB tentang Hukum Laut (United Nation Convention on the Law of the sea 1982)

http://setkab.go.id/pbb-verifikasi-16-056-nama-pulau-indonesia/

Arsyad, R., 2012, Kelautan atau Maritim?, shnews.co, Rabu, 13 Juni 2012 
yang telah disahkan dalam hukum nasional melalui Undang-Undang Nomor 17 Tahun 1985 tentang Pengesahan United Nation Convention on the Law of the sea (Konvensi Perserikatan Bangsa-Bangsa tentang Hukum Laut), namun sampai saat ini pelaksanaan UNCLOS 1982 masih memiliki permasalahan terkait dengan pengimplementasiannya. Indonesia menetapkan jalur pelayaran di dalam ketentuan Alur Laut Kepulauan Indonesia (ALKI) yang membelah perairan kearah utara- selatan. Namun, menjadi permasalahan adalah tuntuan dari negara maritim lainnya yang meminta Indonesia membelah perairan dari timur-barat.

Selain hal di atas setidaknya terdapat tiga permasalahan besar terkait dengan kelautan dan kemaritiman yaitu mengenai batas wilayah, ruang laut dan diplomasi maritim. Tidak dapat dipungkiri masih banyak permasalahan lainnya yang perlu dibenahi terkait kelautan dan kemaritiman. Permasalahan hadir mulai dari penataan ruang laut, hingga pengelolaan sumber daya yang ada di dalamnya. Permasalahan batas wilayah laut dapat dilihat dari kesalahan penetapan penggunaan garis pangkal kepulauan saja yang dapat mendelegitimasi wilayah laut Indonesia, revisi penggunaan garis pangkal yang justru mengurangi luas laut Indonesia, penetapan segmen perbatasan laut dengan negara tetangga yang belum selesai, data luas wilayah darat dan laut yang masih berbedabeda, dan keberadaan dan identitas yang tidak pasti tentang pulau-pulau kecil Indonesia. Dan dalam tulisan ini akan membahas permasalahan terkait dengan menguraikan tumpang tindih kewenangan instansi terkait di dalam pengelolaan ruang laut.

\section{B. Metode Penelitian}

Penelitian hukum yang dilaksanakan merupakan penelitian hukum normatif dengan metode pendekatan yuridis normatif yang menitikberatkan penggunaan bahan atau materi penelitian data sekunder dengan didukungoleh datakepustakaan. Disampingitu, penelitian ini juga menggunakan pendekatan perundang-undangan (statue approach), pendekatan historis (historical approach), dan pendekatan perbandingan (comparative approach). Di lihat dari spesifikasinya, penelitian ini termasuk deskriptif analitis yaitu penelitian yang menggambarkan dan menganalisis permasalahan yang berhubungan dengan Penegakan hukum laut khususnya dan pengelolaan ruang laut pada umumnya. Referensi diperoleh dari beberapa dokumen lainnya seperti hasil penelitian, buku, jurnal ilmiah dan media cetak maupun elektronik.

\section{Pembahasan}

Negara Kesatuan Republik Indonesia (NKRI) telah mendeklarasikan kemerdekaan sejak tanggal 17 Agustus 1945 dan dalam hal kepentingan kelautan, perjuangan untuk mewujudkannya dilakukan melalui Deklarasi Djuanda yang lahir berdasarkan pertimbangan politis, geografis, ekonomis, pertahanan dan keamanan. Di dalam Deklarasi Djuanda, Indonesia menyatakan bahwa teritorial negara Indonesia adalah wilayah yang dikelilingi oleh garis yang menghubungkan titik-titik ujung terluar pada pulau-pulau terluar negara Indonesia selebar 12 mil laut. $^{3}$ 
Pada sidang keduabelas Konferensi PBB tentang Hukum Laut Ketiga, naskah konvensi ditandatangani oleh 119 negara dan resmi menjadi Konvensi PBB tentang Hukum Laut (United Nations Conventions on the Law of The Sea/UNCLOS) 1982 yang terdiri atas 17 bab dan 320 pasal. Konvensi ini menetapkan bahwa lebar laut teritorial maksimal 12 mil laut dan diakuinya konsepsi negara kepulauan. Akan tetapi, kedaulatan perairan kepulauan dalam UNCLOS 1982 dibatasi oleh Hak Lintas Alur Laut Kepulauan atau biasa disebut Hak Lintas Damai. adanya penambahan wilayah laut, laut tidak lagi dianggap sebagai pemisah wilayah sebuah negara, sebaliknya laut dianggap sebagai pemersatu. Oleh sebab itu pengakuan konsepsi Deklarasi Djuanda telah memberikan tanggung jawab yang besar bagi Indonesia dalam mengelola laut secara berkelanjutan untuk kepentingan:

1. Nasional sebagai sumber perekonomian;

2. Regional karena berbatasan laut dengan negara tetangga; dan

Gambar 2.1 : Peta Batas Wilayah Indonesia Berdasarkan TZMKO 1939 (sebelum Deklarasi Djuanda) ${ }^{4}$

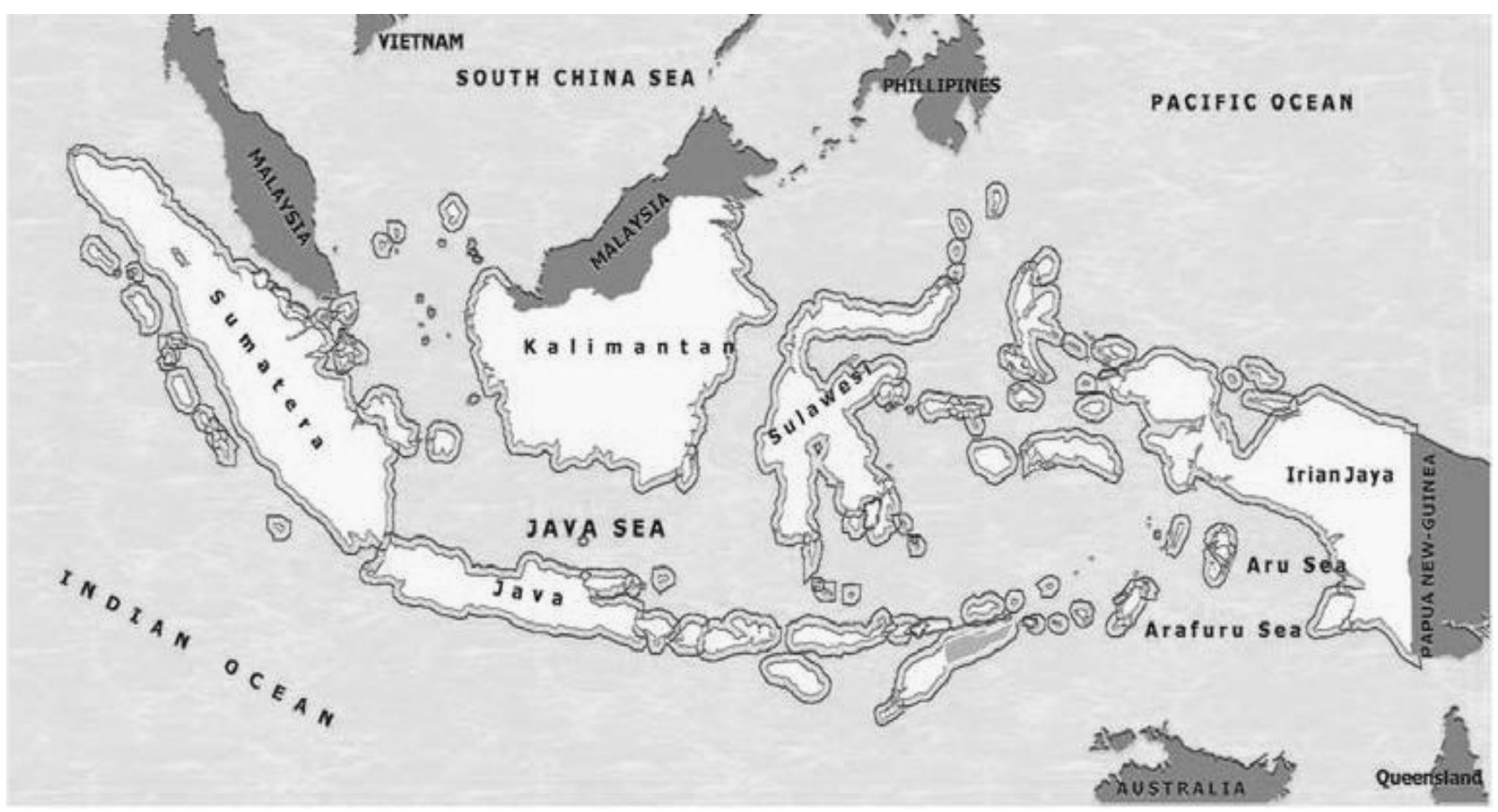

Dengan diakuinya konsepsi Deklarasi Djuanda di dalam UNCLOS 1982, selain
3. Internasional karena perairan Indonesia merupakan perairanvitalyang berpengaruh pada perdagangan internasional. 
Gambar 2.2 : Peta Batas Wilayah Indonesia Setelah Deklarasi Djoeanda ${ }^{5}$

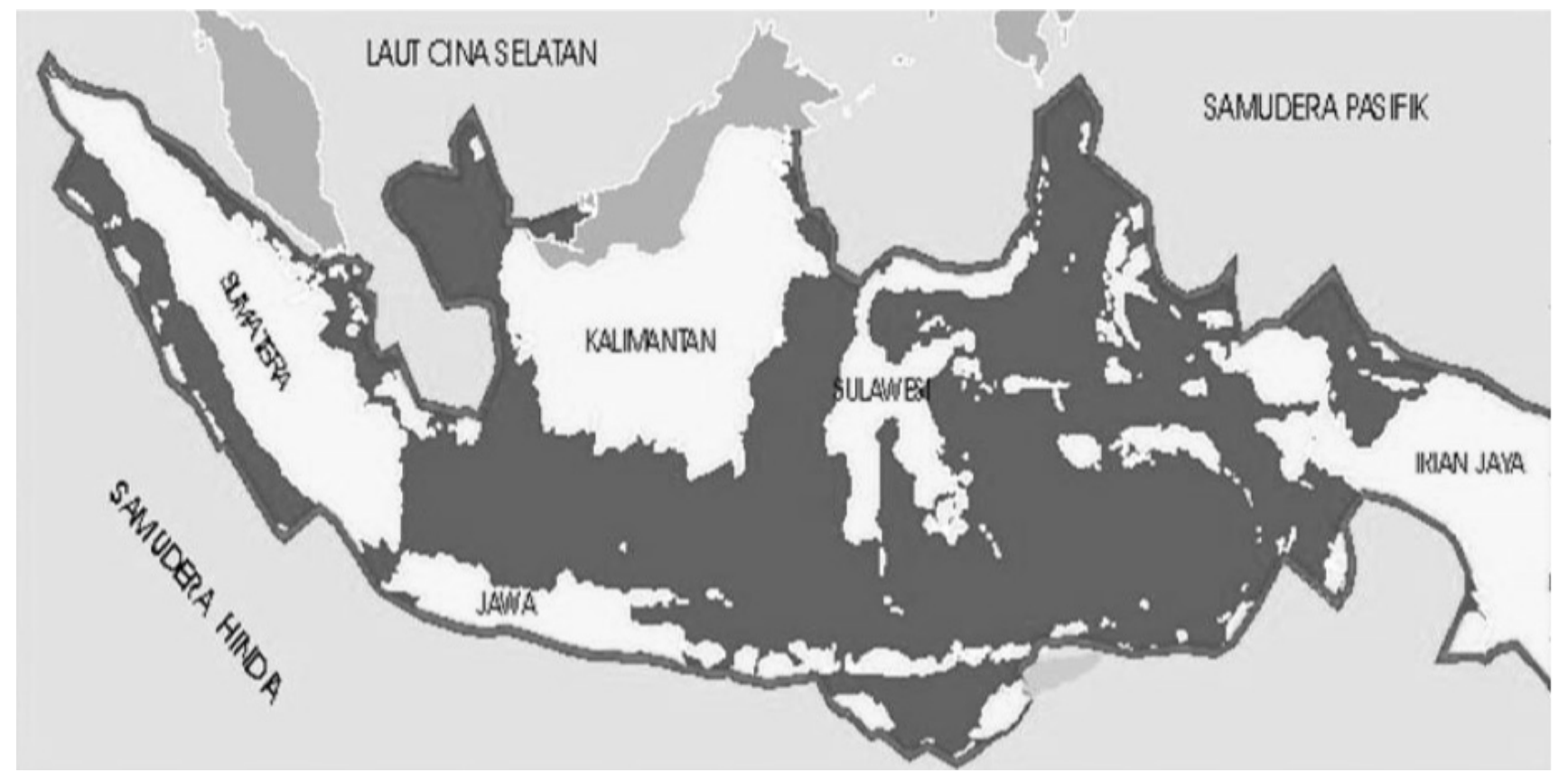

Penambahan luas wilayah laut Indonesia sangatlah signifikan dan harus dilihat bukan saja sebagai aset nasional, tetapi juga merupakan tantangan nyata bahwa wilayah laut harus dikelola, dijaga dan diamankan bagi kepentingan bangsa Indonesia. Seiring dengan bertambahnya luas wilayah laut Indonesia, bertambah pula ancaman, baik yang bersifat faktual maupun ancaman yang bersifat potensi konflik pemanfaatan laut, konflik perbatasan dan potensi konflik lainnya.

Pengakuan Indonesia sebagai negara kepulauan dalam UNCLOS 1982 harus membuat segenap komponen bangsa sadar bahwa Indonesia memiliki ruang hidup (lebenstraum) dengan potensi untuk dikembangkan menjadi negara bahari sebagai manifestasi konsepsi Wawasan Nusantara secara utuh dengan memperhatikan keselarasan dan keterpaduan antara darat, laut dan udara dalam satu kesatuan wilayah, politik dan ekonomi demi kemakmuran seluruh bangsa Indonesia. Wawasan Nusantara adalah konsepsi geopolitik bangsa Indonesia yang merupakan manifestasi pemikiran politik nasional. Berdasarkan UNCLOS 1982 Indonesia mempunyai hak kepentingan internasional yang meliputi wilayah laut bebas dan kawasan di dasar laut internasional di luar Landas Kontinen Indonesia, termasuk kewajibannya.

Konstitusi Negara Republik Indonesia Pasal 25A UUD 1945 (Groundwet) disebutkan bahwa Negara Kesatuan Republik Indonesia (NKRI) adalah sebuah negara kepulauan yang berciri nusantara dengan wilayah, batas-batas dan hak-haknya ditetapkan dengan undangundang (Undang-Undang Nomor 43 Tahun 2008 tentang Wilayah Negara). Dalam hukum internasional sebagaimana diatur Pasal 46 United Nations Convention on the Law of the Sea (UNCLOS 1982) dan telah diratifikasi

5 Ibid., hlm. 10. 
melalui Undang-Undang Nomor 17 Tahun 1985 (LN RI Tahun 1985 Nomor 76) tentang Ratifikasi UNCLOS 1982. Sebagai negara kepulauan, Indonesia memiliki hak penuh atas kedaulatan (sovereignty) wilayah perairan dengan lebar 12 mil mencakup dasar laut dan seisinya, serta ruang udara di atas dari wilayah perairan tersebut dan hak berdaulat (sovereignty right) terhadap perairan zona ekonomi ekslusif, zona tambahan dan landas kontinen. ${ }^{6}$

Di zona tambahan, Indonesia memiliki kewenangan untuk melakukan penegakan hukum di bidang kepabeanan, perpajakan (fiskal), imigrasi, karantina, dan kesehatan (sanitasi). Di Zona Ekonomi Eksklusif (ZEE), Indonesia memiliki hak berdaulat untuk melakukan pengelolaan sumber daya kolom air. Sementara itu, di landas kontinen, Indonesia memiliki kewenangan untuk mengatur dan mengelola dasar laut dan kekayaan di bawahnya.

Indonesia juga memiliki hak berdaulat di landas kontinen di luar 200 mil laut hingga maksimal 350 mil laut apabila Indonesia dapat membuktikan secara ilmiah. Pelaksanaan dari kedaulatan dan hak berdaulat Indonesia di berbagai zona maritim tersebut harus sejalan dengan hukum internasional dan memperhatikan kepentingan strategis Indonesia, khususnya yang berkaitan dengan usaha menjamin keutuhan wilayah negara, menjaga kedaulatan negara dan kepentingan kesejahteraan segenap bangsa. Selain itu, aspek geostrategis dan geopolitik, baik kawasan regional maupun internasional harus menjadi salah satu elemen pertimbangan di dalam melaksanakan berbagai hal yang menjadi bagian dari penegakan kedaulatan dan hak berdaulat Indonesia di perairannya. ${ }^{7}$

Dewasa ini, Indonesia memiliki 8 (delapan) masalah utama di dalam sektor laut:

1. Tata batas wilayah laut Indonesia yang belum jelas;

2. Penataan ruang laut belum lengkap dan parsial;

3. Peraturan perundang-undangan yang belum lengkap dan masih tumpang tindih;

4. Pencemaran dan kerusakan di laut;

5. Lemahnya pengawasan dan penegakan hukum di laut;

6. Sistem data dan informasi terkait wilayah laut, penggunaan ruang laut dan pemanfaatannya belum lengkap dan tidak terintegrasi;

7. Belum optimalnya penerimaan negara;

8. Belum optimalnya program pemerintah untuk meningkatkan kesejahteraan masyarakat yang menggantungkan hidupnya pada laut.

Kedelapan permasalahan di atas merupakan permasalahan mendasar yang perlu diatasi bersama dalam rangka mewujudkan laut Indonesia yang berdaulat dan berkelanjutan. Dalam perkembangannya, berbagai fakta menunjukkan bahwa salah satu permasalahan terbesar di laut adalah masih banyaknya tindak kejahatan yang terjadi, baik berupa pencurian sumber daya alam laut, perompakan, maupun berbagai kejahatan lintas negara (transnational crime) di laut masih tetap terjadi.

Permasalahan terkait dengan penegakan hukum di laut dapat dikatakan cukup

6 Jeffrey Rewis, Menjahit Laut yang Robek Paradigma Archipelago State Indonesia, Yayasan Malesung, Jakarta, 2004, hlm. Xii.

7 Peraturan Presiden Nomor 16 Tahun 2017 tentang Kebijakan Kelautan Nasional, Bab II, Lampiran I. 
kompleks dan membutuhkan perhatian lebih dari pemerintah dan seluruh pihak terkait. Permasalahan yang ada selama ini merupakan permasalahan yang cukup mendasar yang sepatutnya harus diselesaikan sejak dini satu persatu. Namun sayangnya, dalam proses penegakan tidak hanya terdapat permasalahan dari luar, namun ada satu permasalahan yang sampai saat ini belum terpecahkan dan itu berasal dari dalam pemerintah Indonesia sendiri. Keadaan di lapangan menunjukan bahwa penegakan hukum, keamanan dan keselamatan di laut diatur oleh banyak instansi yang berkecimpung di laut dan masih belum sesuai dengan harapan, karena kementerian/ lembaga terkait di laut dalam melaksanakan kegiatan operasi keamanan dan keselamatan di laut masing-masing mempunyai strategi/ kebijakan, peralatan (sarana prasarana) dan sumber daya manusia yang berbeda-beda, tidak dalam satu sistem yang terkoordinasi, tersinergi dan terintegrasi

Fenomena ini dapat terjadi disebabkan oleh beberapa hal dan yang menjadi penyebab utama dari fenomena tersebut adalah terdapat banyak regulasi yang telah mengaturnya dan dengan banyaknya regulasi menjadi alasan dasar dari seluruh instansi terkait dalam melaksanakan kewenangannya dalam penegakan hukum di laut. Peraturan perundang undangan di Indonesia yang mengatur terkait kelautan dan kemaritiman, pada tahun 2019 ini Pusat Analisis dan Evaluasi Hukum Nasional Badan Pembinaan Hukum Nasional kembali mengangkat terkait Sumber Daya Kelautan dan Kemaritiman. Hasil inventarisir dari Pokja tersebut terdapat 10 Undang-Undang terkait Sumber Daya Kelautan dan Kemaritiman, sebagai berikut:
1. Undang-Undang Nomor 5 Tahun 1983 tentang Zona Ekonomi Eksklusif Indonesia;

2. Undang - Undang Nomor 5 Tahun 1990 tentang Konservasi Sumber Daya Alam Hayati dan Ekosistemnya;

3. Undang-Undang Nomor 10 Tahun 1995 tentang Kepabeanan sebagaimana diubah dengan Undang-Undang Nomor 17 Tahun 2006 tentang Kepabeanan;

4. Undang-Undang Nomor 6 Tahun 1996 tentang Perairan Indonesia;

5. Undang-Undang Nomor 26 Tahun 2007 tentang Penataan Ruang;

6. Undang-Undang Nomor 17 Tahun 2008 tentang Pelayaran;

7. Undang-Undang Nomor 43 Tahun 2008 tentang Wilayah Negara;

8. Undang-Undang Nomor 31 Tahun 2004 tentang Perikanan sebagaimana diubah dengan Undang-Undang Nomor 45 Tahun 2009;

9. Undang-Undang Nomor 27 Tahun 2007 sebagaimana telah diubah dengan Undang-Undang Nomor 1 Tahun 2014 tentang Pengelolaan Wilayah Pesisir dan Pulau-Pulau Kecil;

10. Undang-Undang Nomor 32 Tahun 2014 tentang Kelautan.

Selain 10 (sepuluh) Undang-undang yang telah disebutkan diatas, masih terdapat banyak peraturan lainnya yang juga mengaturnya, selain itu peraturan pelaksana dari UndangUndang tersebut juga tidak kalah banyaknya yang harus lebih diperhatikan. Masalah regulasi merupakan satu isu tersendiri yang menjadi salah satu akar permasalahan terkait kelautan dan kemaritiman di Indonesia. Regulasi yang masih terus berkembang sampai saat ini mengandung banyaknya ego sektoral yang begitu kental. 
Gambar 2.3 : Kondisi Penanganan Tindak Pidana di Laut ${ }^{8}$

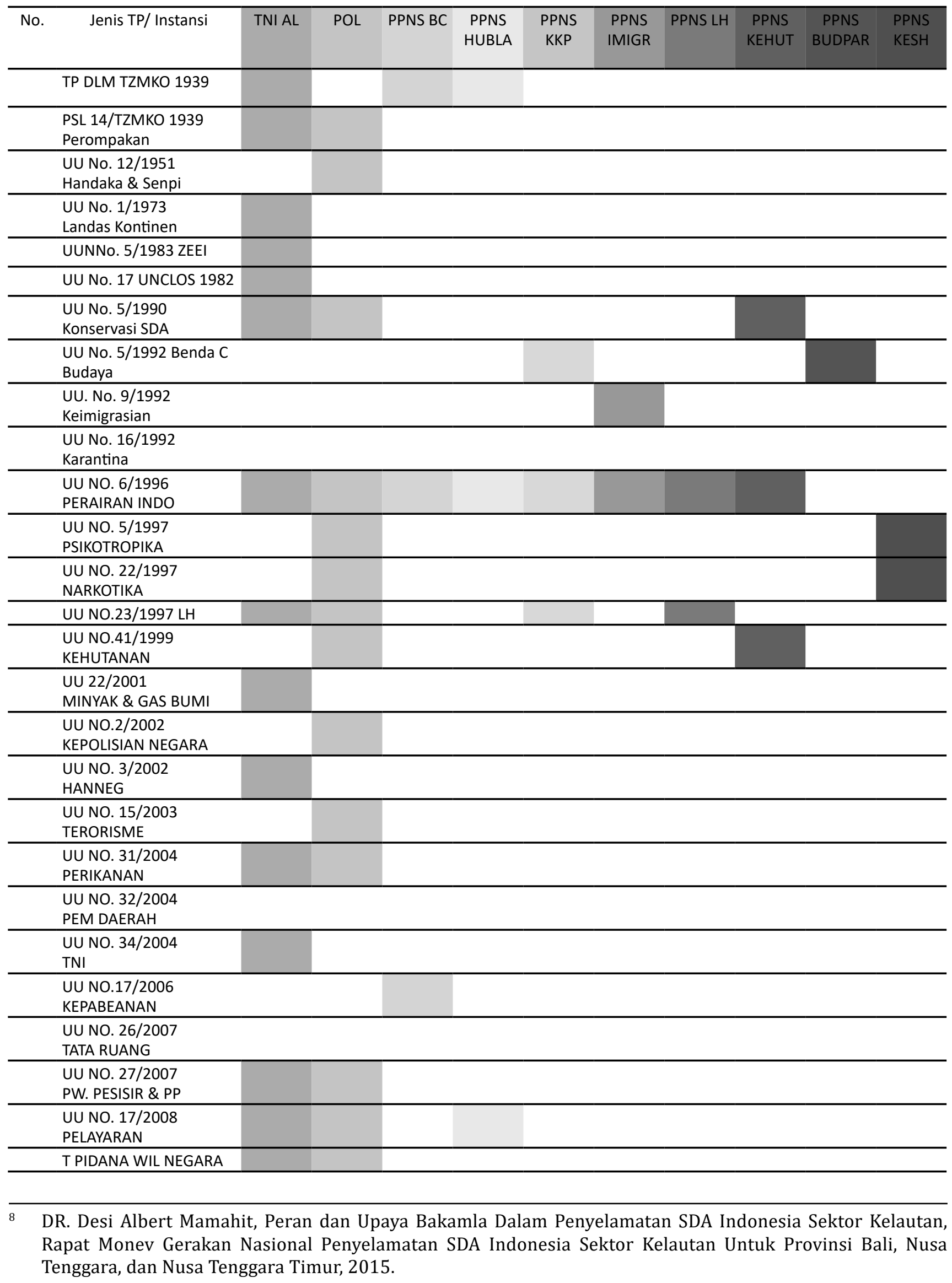


Gambar diatas merupakan data yang di dapat pada tahun 2015. Pada tabel tersebut dapat dilihat tumpang tindih kelembagaan di Indonesia terkait dengan tugas dan fungsi terkait kelautan dan kemaritiman. Disharmoni pengaturan antar kelembagaan tersebut merupakan satu hal yang sudah menjadi rahasia umum. Dampak dari ada banyaknya lembaga yang mengatur mengenai kelautan dan kemaritiman adalah timbulnya banyak pengaturan mengenai bidang kelautan dan kemaritiman.

Regulasi yang ada selama ini merupakan regulasi yang mengatur segala aspek yang ada pada bidang kelautan di Indonesia, dan salah satu dampak dari banyaknya regulasi tersebut adalah timbungnya tumpang tindih kewenangan dari instansi-instansi terkait. Pada Tahun 2016, Pusat Analisis dan Evaluasi Hukum Nasional Badan Pembinaan Hukum Nasional telah melakukan evaluasi terhadap tumpang tindih pengaturan terhadap kelembagaan di Indonesia melalui Kelompok
Kerja Analisis dan Evaluasi Hukum terkait Pemberantasan Perikanan Liar (IUU Fishing), dari apa yang telah dianalisis oleh kelompok kerja tersebut didapatkan bahwa yang telah dilakukan oleh Pusat Analisis dan Evaluasi Hukum Nasional yaitu terdapat tiga instansi yang berwenang dalam penegakan hukum perikanan berdasarkan Pasal 73 UU No. 45 Tahun 2009, yaitu Kementerian Kelautan dan Perikanan (KKP), TNI Angkatan Laut dan Polri. Akan tetapi Undang-Undang ini tidak mengatur pembagian kewenangan secara jelas dan mekanisme kerja yang pasti. Sehingga ketiga instansi tersebut memiliki kewenangan yang sama dalam penegakan hukum perikanan tanpa ada keterpaduan sistem pelaksanaannya. Hal ini menyimpan potensi konflik kewenangan, karena ketiganya memiliki wewenang dalam menangani perkara yang sama, misalnya dalam hal penyidikan dan pemberkasan BAP (kecuali bagi TNI AL di ZEEI). (Tabel Analisis pada Bagian Bawah)

\begin{tabular}{|c|c|c|c|c|c|}
\hline $\begin{array}{l}\text { UU No. } 31 \text { / 2004Jo. } \\
\text { UU No. } 45 \text { /2009 } \\
\text { tentang Perikanan }\end{array}$ & $\begin{array}{l}\text { UU No. } 32 \text { / } 2014 \\
\text { tentang Kelautan }\end{array}$ & $\begin{array}{l}\text { UU No. } 17 \text { / } 2008 \\
\text { tentang Pelayaran }\end{array}$ & $\begin{array}{c}\text { UU NO. } 34 \text { / } 2004 \\
\text { Tentang TNI }\end{array}$ & $\begin{array}{l}\text { Perpres No. } 178 \text { /2014 } \\
\text { Tentang Bakamla }\end{array}$ & $\begin{array}{c}\text { Perpres } \\
\text { No.115 / } 2015 \\
\text { Tentang Satgas } \\
\text { Pemberantasan } \\
\text { Illegal Fishing }\end{array}$ \\
\hline $\begin{array}{l}\text { Pasal 69: } \\
\text { (1) Kapal pengawas } \\
\text { perikanan } \\
\text { berfungsi } \\
\text { melaksanakan } \\
\text { pengawasan } \\
\text { dan penegakan } \\
\text { hukum di bidang } \\
\text { perikanan } \\
\text { (3) Kapal pengawas } \\
\text { perikanan dapat } \\
\text { menghentikan, } \\
\text { memeriksa, } \\
\text { membawa, dan } \\
\text { menahan kapal } \\
\text { yang diduga atau } \\
\text { patut diduga } \\
\text { melakukan } \\
\text { pelanggaran } \\
\text { di wilayah } \\
\text { pengelolaan } \\
\text { perikanan } \\
\text { Republik Indonesia }\end{array}$ & $\begin{array}{l}\text { Pasal 62: } \\
\text { Fungsi BAKAMLA : } \\
\text { a. menyusun kebijakan } \\
\text { nasional di bidang } \\
\text { keamanan dan } \\
\text { keselamatan di } \\
\text { wilayah perairan } \\
\text { Indonesia dan } \\
\text { wilayah yurisdiksi } \\
\text { Indonesia; } \\
\text { b. menyelenggarakan } \\
\text { sistem peringatan } \\
\text { dini keamanan dan } \\
\text { keselamatan di } \\
\text { wilayah perairan } \\
\text { Indonesia dan } \\
\text { wilayah yurisdiksi } \\
\text { Indonesia; } \\
\text { c. melaksanakan } \\
\text { penjagaan, } \\
\text { pengawasan, } \\
\text { pencegahan, } \\
\text { dan penindakan } \\
\text { pelanggaran hukum }\end{array}$ & $\begin{array}{l}\text { Pasal } 278 \text { ayat b (1): } \\
\text { penjaga laut dan } \\
\text { pantai mempunyai } \\
\text { kewenangan untuk: } \\
\text { a. melaksanakan } \\
\text { patroli laut; } \\
\text { b. melakukan } \\
\text { pengejaran } \\
\text { seketika (hot } \\
\text { pursuit); } \\
\text { memberhentikan } \\
\text { dan memeriksa } \\
\text { kapal di laut; dan } \\
\text { d. melakukan } \\
\text { penyidikan. } \\
\text { (ket: mandat kepada } \\
\text { Polri) } \\
\text { Pasal } 340 \text { : } \\
\text { penegakan hukum } \\
\text { pada perairan Zona } \\
\text { Ekonomi Eksklusif. } \\
\text { (ket: Mandat kepada } \\
\text { TNI AL) }\end{array}$ & $\begin{array}{l}\text { Pasal } 7 \text { ayat (2): } \\
\text { Kewenangan TNI di } \\
\text { antaranya: } \\
\text { 5. mengamankan } \\
\text { objek vital } \\
\text { nasional } \\
\text { yang bersifat } \\
\text { strategis; } \\
\text { 14. membantu } \\
\text { pemerintah } \\
\text { dalam } \\
\text { pengamanan } \\
\text { pelayaran dan } \\
\text { penerbangan } \\
\text { terhadap } \\
\text { pembajakan, } \\
\text { perompakan, } \\
\text { dan } \\
\text { penyelundupan. }\end{array}$ & $\begin{array}{l}\text { Pasal 3: } \\
\text { Kewenangan Bakamla: } \\
\text { a. } \text { menyusun } \\
\text { kebijakan } \\
\text { nasional di bidang } \\
\text { keamanan dan } \\
\text { keselamatan di } \\
\text { wilayah perairan } \\
\text { Indonesia dan } \\
\text { wilayah yurisdiksi } \\
\text { Indonesia; } \\
\text { b. } \text { menyelenggarakan } \\
\text { sistem peringatan } \\
\text { dini keamanan dan } \\
\text { keselamatan di } \\
\text { wilayah perairan } \\
\text { Indonesia dan } \\
\text { wilayah yurisdiksi } \\
\text { Indonesia; } \\
\text { c. } \text { melaksanakan } \\
\text { penjagaan, } \\
\text { pengawasan, } \\
\text { pencegahan, dan } \\
\text { penindakan }\end{array}$ & $\begin{array}{l}\text { Pasal } 3 \text { : } \\
\text { Kewenangan Satgas } \\
\text { 115: } \\
\text { a. Menentukan } \\
\text { target operasi; } \\
\text { b. Melakukan } \\
\text { koordinasi; } \\
\text { c. Membentuk } \\
\text { dan } \\
\text { memerintahkan } \\
\text { unsur-unsur } \\
\text { Satgas untuk } \\
\text { melakukan } \\
\text { penegakan } \\
\text { hokum; } \\
\text { d. Melaksanakn } \\
\text { komando dan } \\
\text { pengendalian. }\end{array}$ \\
\hline
\end{tabular}




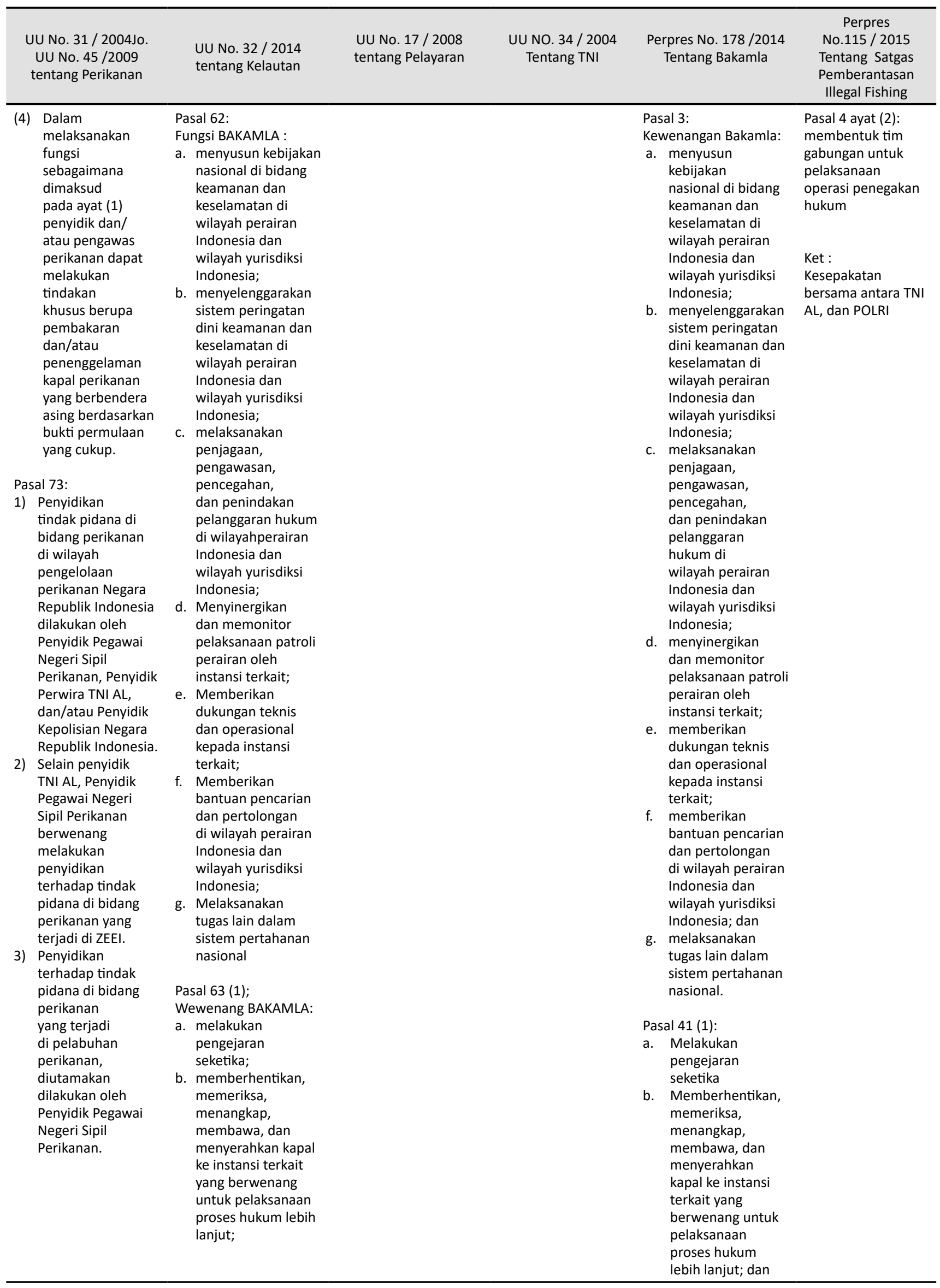




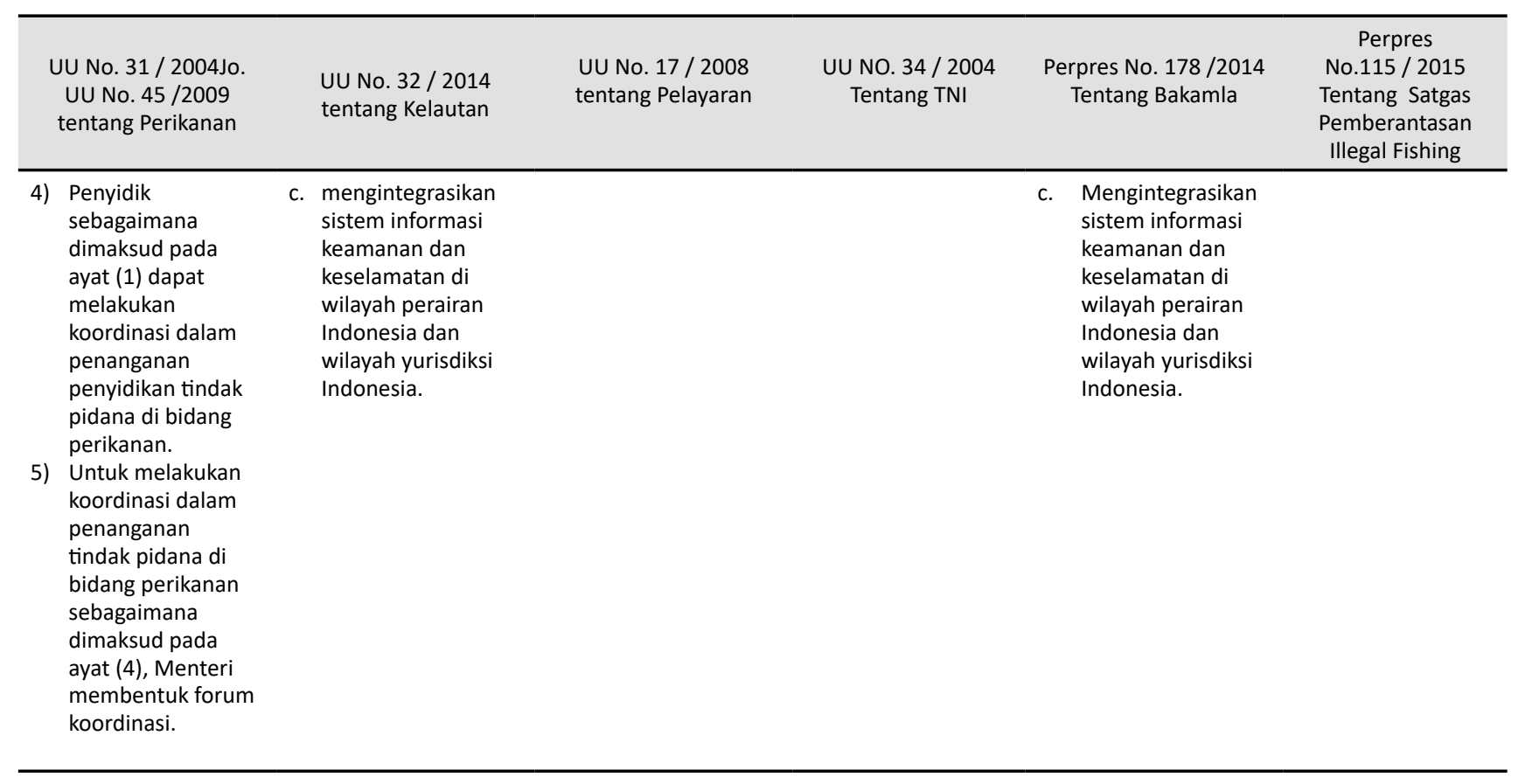

Dari yang telah dipaparkan diatas maka dapat disimpulkan bahwa terkait penegakan hukum di bidang kelautan dan kemaritiman terdapat dua masalah dasar dan penting untuk diatasi bersama, yaitu: kewenangan antar lembaga yang mengatur terkait kelautan dan kemaritiman yang saling berseberangan dan masih kuatnya ego sektoral antar kelembagaan, dan tumpang tindih pengaturan terkait kelautan dan kemaritiman. Dalam hal kewenangan antar lembaga, perlu adanya tindakan tegas untuk merangkul seluruh lembaga di Indonesia yang mengatur penegakan hukum di laut agar adanya koordinasi yang lebih baik guna mendukung terciptanya ketertiban di laut Indonesia. Semua ini dapat teratasi salah satunya dengan penataan regulasi di bidang kelautan dan kemaritiman. Dapat dikatakan bahwa tumpang tindih kewenangan antar lembaga di bidang kelautan dan perikanan disebabkan oleh peraturan perundangundangan yang terlalu memaksa, bahkan di dalam salah satu peraturan perundang- undangan terdapat turunan dari UndangUndang yang memberikan kewenangan kepada penegak hukum di laut yang melampaui undang-undang itu sendiri dan ini harus dapat kita atasi bersama. Dengan penegakan hukum yang ideal maka akan mewujudkan laut Indonesia yang berdaulat dan berkelanjutan untuk masa depan bangsa Indonesia.

\section{Penutup}

Sebagai salah satu sumber pemasukan terbesar bagi rakyat Indonesia, laut merupakan satu hal yang sangat penting, ditambah dengan Indonesia sebagai negara kepulauan. Dalam pembahasan di atas dapat disimpulkan bahwa penegakan hukum di Indonesia sendiri masih memiliki permasalahan dasar yang perlu ditangani bersama yaitu penataan regulasi terhadap kewenangan seluruh instansi dalam hal penegakan hukum di laut Indonesia. Tidak hanya itu, koordinasi antar penegak hukum masih dikatakan lemah sehingga dapat 
menimbulkan tumpang tindih kewenangan. Kebijakan masing-masing instansi juga sangat rawan menimbulkan konflik kepentingan dan koordinasi antar berbagai instansi tersebut sangat menentukan keberhasilan dalam penegakan hukum di laut Indonesia.

Seperti yang diutarakan oleh Prof. Dr. Hasjim Djalal, M.A. di dalam bukunya yang berjudul 'Negara Kepulauan Menuju Negara Maritim" bahwa Indonesia membutuhkan empat hal di dalam membangun negara maritim yang kuat yaiut, 1) formula ocean policy yang jelas dan dipahami oleh semua pihak dan menjadi pegangan di dalam merancang peta kepentingan nasional (di laut); 2) strategi keamanan maritim, yang pada prinsipnya mencakup tiga hal yang mendasar yaitu ends, means and ways; 3) konstruksi manajemen keamanan maritim yang menjelaskan siapa berbuat apa dalam kapasitas apa di dalam "bingkai" strategi keamanan maritim; dan 4) landasan hukum, yang menjadi dasar operasionalisasi kegiatan dan pengamanan potensi maritim.

Oleh karena itu guna mewujudkan laut Indonesia yang berdaulat dan berkelanjutan dibutuhkan penatan regulasi dan rasa memiliki yang tinggi dengan menumbuhkan rasa toleransi dan bekerjasama antar instansi terkait agar terwujudnya pengelolaan ruang laut yang berdaulat dan berkelanjutan.

\section{Daftar Pustaka}

\section{Buku}

Djalal, Hasjim, Negara Kepulauan Menuju Negara Maritim (Jakarta: Lembaga Laut Indonesia, 2010).
Rewis, Rey, Menjahit Laut yang Robek Paradigma Archipelago State Indonesia (Jakarta: Yayasan Malesung, 2004).

\section{Makalah/Artikel/Laporan/Hasil Penelitian}

Dewan Kelautan Indonesia, "Evaluasi Kebijakan Dalam Rangka Implementasi Konvensi Hukum Laut Internasional (UNCLOS 1982) di Indonesia" (Departemen Kelautan dan Perikanan, Sekretatiat Jenderal Satuan Kerja Dewan Kelautan Indonesia, Jakarta, 2008).

Mamahit, Desi Albert, "Peran dan Upaya Bakamla Dalam Penyelamatan SDA Indonesia Sektor Kelautan" (Rapat Monev Gerakan Nasional Penyelamatan SDA Indonesia Sektor Kelautan Untuk Provinsi Bali, Nusa Tenggara, dan Nusa Tenggara Timur, 2015).

Pusat Analisis dan Evaluasi Hukum Nasional BPHN, (Laporan Akhir Kelompok Kerja Analisis dan Evaluasi Hukum dalam rangka Pemberantasan Kegiatan Perikanan Liar (IUU Fishing), Jakarta: BPHN, 2016).

\section{Peraturan}

Undang-Undang Nomor 31 Tahun 2004 tentang Perikanan sebagaimana diubah dengan Undang-Undang Nomor 45 Tahun 2009.

Undang-Undang Nomor 32 Tahun 2014 tentang Kelautan.

Peraturan Presiden Nomor 16 Tahun 2017 tentang Kebijakan Kelautan Nasional, Bab II, Lampiran I.

\section{Internet}

http://setkab.go.id/pbb-verifikasi-16-056-namapulau-indonesia/

Arsyad, R., 2012, “Kelautan atau Maritim?", http:// shnews.co, (Rabu, 13 Juni 2012). 